\title{
Genome editing: propelling the next generation of crop improvement
}

\author{
Jéssika Angelotti-Mendonça ${ }^{{ }^{*}}$, Alessandra Koltun ${ }^{2 *}$, Fernanda Freitas de Oliveira ${ }^{2}$, Nathalia Volpi e Silva ${ }^{1}$ \\ ${ }^{1}$ Empresa Brasileira de Pesquisa Agropecuária - Embrapa Soja, Londrina, PR. ${ }^{2}$ Universidade Estadual de Maringá - \\ UEM, PR. E-mail: nathvolpi.Ibi@gmail.com \\ * JA-M and AK contributed equally to this work.
}

\begin{abstract}
Climate change and population size records threaten food security. Therefore, the call for a more sustainable and efficient crop production has never been more urgent. Traditional plant breeding was one of the first successful approaches to expand cultivation areas and crop yield. Later, biotechnological tools and their products, such as genetically modified organisms containing exogenous DNA, further broadened the limits of agricultural results, yet bringing huge financial, bureaucratic, and public rejection hurdles. In the 90s, scientific advances brought the opportunity to drive mutations using engineered nucleases, and since 2013 CRISPR-Cas has emerged as the most practical toolkit to edit genomes. One of the most striking possibilities is to generate edited and non-transgenic plants. In this review, we present the working mechanism behind CRISPR-induced mutations and pinpoint the latest techniques developed, as well as its myriad of applications in agriculture. The enhancing scope of CRISPR ranges from introducing traits of agronomic interest - such as herbicide resistance, resistance/tolerance to biotic and abiotic stresses, and quality and durability of products - to accelerating plant breeding processes, including haploid induction, generating male-sterile lines, fixating hybrid vigor, and overcoming self-incompatibility. We also discuss regulatory issues surrounding edited plants and derived products around the world, challenges that must be overcome, and future prospects to harness all the potential of this amazing tool to guarantee the new crop production revolution.
\end{abstract}

Keywords: CRISPR-Cas; engineered nucleases; targeted mutations; precision plant breeding; agriculture.

\section{Edição genômica: impulsionando a nova geração do melhoramento de plantas}

\section{Resumo}

As mudanças climáticas e números recordes de população ameaçam a segurança alimentar. Portanto, o apelo por uma produção agrícola mais sustentável e eficiente nunca foi tão urgente. O melhoramento genético tradicional foi uma das primeiras abordagens bem-sucedidas para expandir as áreas de cultivo e o rendimento das safras. Posteriormente, ferramentas biotecnológicas e seus produtos, como organismos geneticamente modificados contendo DNA exógeno, ampliaram ainda mais os limites dos resultados agrícolas, apesar de ainda carregarem enormes obstáculos financeiros, burocráticos e de rejeição pública. $\mathrm{Na}$ década de 90 , os avanços científicos trouxeram a oportunidade de conduzir mutações usando nucleases projetadas e, desde 2013, CRISPR-Cas surgiu como o kit de ferramentas mais prático para editar genomas. Uma das possibilidades mais marcantes é gerar plantas editadas e não transgênicas. Nesta revisão, apresentamos o mecanismo de ação por trás das mutações induzidas por CRISPR, identificando as últimas técnicas desenvolvidas, bem como sua miríade de aplicações na agricultura. O escopo de aprimoramento do CRISPR varia desde introduzir características de interesse agronômico - como resistência a herbicidas, resistência/tolerância a estresses bióticos e abióticos e qualidade e durabilidade de produtos - até acelerar processos de melhoramento genético de plantas, incluindo indução de haploidia, geração de linhagens macho-estéreis, fixação de vigor híbrido e superação da autoincompatibilidade. Também discutimos questões regulatórias em torno de plantas editadas e produtos derivados mundialmente, desafios que devem ser superados e perspectivas futuras para aproveitar todo o potencial desta ferramenta incrível para garantir a nova revolução na produção de culturas agrícolas.

Palavras-chave: CRISPR-Cas; nucleases projetadas; mutações direcionadas; melhoramento de plantas de precisão; agricultura. 


\section{Introduction}

Since its discovery more than 10,000 years ago, agriculture has allowed civilization to exist and evolve. The need for improving the efficiency of agricultural systems to produce food and energy for an ever-growing population drove humans to create increasingly sophisticated techniques in vast areas. Among the strategies to push agriculture limits further, plant breeding has played a crucial role, setting new records regarding yield and tolerance to biotic and abiotic stressors. Crop improvement has a lively history and can be divided into 4 major benchmarks: traditional breeding, induced mutagenesis, genetically modified organisms (GMOs), and genome editing (GAO, 2021).

Traditional plant breeding aims to combine desirable traits through crossings. Although it has brought crucial advances for agriculture, it relies on and is limited to the genetic variability present in the species of interest and related crossable species, in addition to being laborious and time-consuming. Induced mutagenesis came to boost the naturally occurring mutation rates and create genetic variability that could occasionally result in a desired trait. However, the screening of large populations to find the plant harboring the trait of interest derived from the random mutation makes this strategy unfeasible for highly complex agronomic traits (HOLME et al., 2019).

The advent of recombinant DNA technology has made it possible to isolate and clone genes from the most diverse organisms, overcoming isolation barriers between species and even kingdoms. These exogenous DNA fragments can be introduced and expressed in plants, opening up a wide range of possibilities for the genetic improvement of crops (ANAMI et al., 2013). GMOs have contributed to obtaining superior varieties, leading to higher yields, herbicide and pest resistance, and improved nutrition. Even though this technique broadened plant breeding, the organisms harboring randomly integrated foreign DNA are subjected to strict government regulations that are highly onerous to follow, strongly limiting the potential parties involved in GM crop creation and commercialization and the range of products available (RAMAN, 2017). The misled public opinion also hampers the full potential of GMOs (BRADFORD et al., 2005).

Genome editing has emerged as the most recent breakthrough for basic and applied plant research with the rise of RNA-guided nucleases. The clustered regularly interspaced short palindromic repeats (CRISPR)-Cas (CRISPR associated proteins) system represents its most advanced yet practical and affordable toolkit, allowing researchers to delete, replace, or insert specific DNA sequences in a predictable and targeted way (FENG et al., 2013; SHAN et al., 2013). It greatly expanded the initial genome engineering scope from GMO in terms of manipulating traits, and it offers DNA-free routes (WOO et al., 2015) or that leaves no traces of foreign DNA (HE; ZHAO, 2020), possibly circumventing the burden of lengthy approval processes, depending on the path legislation takes.

New and genius spined-off techniques are being rapidly created and refined (ANZALONE et al., 2019; KATREKAR et al., 2019). These increasingly more effective and time-saving techniques have already been applied to upgrade a variety of crops (SHIMATANI et al., 2017; ZONG et al., 2017; CHEN et al., 2019b; LIN et al., 2020; ZHANG et al., 2020b; ZHU et al., 2020), unimaginably expanding the horizon of possibilities in this field and giving rise to the next generation of crop improvement.

Scientific breakthroughs and technological innovations in crop production, such as genome editing aligned with modern plant breeding techniques, are urgently needed to secure global food status. Our current system is collapsing and will not be able to feed $\sim 10$ billion people, a population number that will be reached in a not very far period - 2050 (FAO, 2017; SPRINGMANN et al., 2018). Moreover, the global environmental situation leads to seeking more conscious, sustainable, and holistic approaches.

In this review, we will cover 1) an introduction to the CRISPR genome-editing technique in plants, 2) practical applications in crop improvement, 3) regulatory issues, 4) challenges and prospects of this outstanding novelty regarding the agricultural scenario.

\section{The CRISPR-cas system and cas variations}

As a biotechnological tool, the main used CRISPR-Cas system has two components: the CRISPR-associated (Cas) nuclease, with Cas9 from Streptococcus pyogenes being the most 
commonly used, and the guide RNA (gRNA); both forming the Cas9:gRNA complex (JINEK et al. 2012; DOUDNA; CHARPENTIER 2014). Cas9 induces DNA double-strand breaks (DSBs) guided by a base-paired structure formed with a chimeric gRNA, resulting from the fusion of a trans-activating CRISPR RNA (tracrRNA), with structural purposes, and the CRISPR RNA (crRNA), containing a 20-nt complementary sequence to the target DNA (JINEK et al., 2012; DOUDNA; CHARPENTIER, 2014). Thereby, Cas9 recognizes the target region based on the base-pairing complementarities with the gRNA. In addition, for the system to function, the target DNA must be near a protospacer adjacent motif (PAM) that varies according to the nuclease. For instance, Cas9 recognizes the PAM sequence NGG found directly downstream of the target DNA on the non-target strand (ANDERS et al., 2014). The cleaving properties of the RNA-guided endonucleases lie on two catalytic domains: $\mathrm{HNH}$ and RuvC, each cutting a DNA strand (FURUHATA; KATO, 2021). The CRISPR-Cas system goes as far as creating the DSBs in a targeted and precise manner. Then, the cellular DNA repair pathways are accounted to try and repair the damaged DNA, eventually creating or introducing a mutation.

Plant cell machinery counts on two main pathways to repair DSBs in somatic cells: nonhomologous end-joining (NHEJ) and homologous recombination (HR). DSBs created by the CRISPRCas system may be repaired by one of these mechanisms and when the route chosen is the error-prone system NHEJ, mutations may be generated in a specific site but in a random manner (PUCHTA et al., 1993, 1996; GORBUNOVA; LEVY, 1997; SALOMON; PUCHTA, 1998). These mutations can be small deletions or insertions, also known as indels, and may change the gene reading frame, affecting the correct protein translation (VOYTAS; GAO, 2014). Usually, when aiming to knockout a gene or generate small mutations, without the need for specific changes in the sequence, the strategy is designed focusing on NHEJ. It represents an efficient approach considering that NHEJ is the preferred repair pathway in plant somatic cells, and it only requires the delivery of a nuclease and one or more gRNAs (PUCHTA, 2005; JINEK et al., 2012). CRISPR-Cas can also be designed to make two DSBs simultaneously, leading to complete deletion of a target gene or fragment (VOYTAS; GAO, 2014), or even to target multiple sequences at the same time. For instance, several genes from a metabolic pathway may be mutated simultaneously (LI et al., 2018; SÁNCHEZ-LEÓN et al., 2018).

As for the HR repair pathway, it enables the insertion of large DNA sequences or even to perform specific changes in the target DNA. Although this system is less efficient than NHEJ, it brings the possibility to induce more accurate changes in the genome, magnifying the possibilities of manipulating plant metabolism, physiology, and products. The HR repair pathway uses homologous templates to repair the DSBs, usually the corresponding sister-chromatid. When manipulating this system to our favor, we provide a donor template to the cell containing the desired mutation and flanked by sequences that are similar to the DSBs surroundings, aiming to mimic a sister chromatid and trick the cell (HUANG; PUCHTA, 2019). Thereby, the HR pathway may use the provided donor instead of the sister-chromatid to repair the DSB, which usually happens more efficiently when the donor sequences provided are abundant. As the researcher can design different types of donor templates, HR offers several possibilities for manipulating plant genomes with a high level of accuracy, such as targeted gene knock-in, alterations of key amino acid residues within a gene's coding sequence, or specific changes in promoter elements or other cis-acting motifs that modulate gene expression (VOYTAS; GAO, 2014). Collectively, these findings make the CRISPR-Cas system a powerful tool for genome editing considering the high frequency of PAM in genomes, besides different PAMs required by other nucleases; theoretically, any gene could be engineered.

Even though Cas9 is the most used nuclease to date, other nucleases are available to be used as part of the CRISPR-Cas genome editing tool, such as Cas12a and Cas13. Cas12a is structurally similar to Cas9, also presenting a RuvC-like domain. However, instead of the HNH domain, it possesses a Nuc domain (SCHINDELE et al., 2018). In addition, Cas12a does not require a tracrRNA in its gRNA structure to mediate its activity and it recognizes a T-rich PAM (5'-TTTN) (SCHINDELE et al., 2018). In contrast to Cas9, which generates blunt-end DSBs proximal to the PAM, Cas12a generates overhanging-end DSBs distal from the PAM (SCHINDELE et al., 2018) and, for this reason, it is usually preferred for CRISPRCas editing by HR (recently reviewed by VOLPI; 
SILVA et al., 2020). On the other hand, the CRISPR-Cas13a system acts exclusively on RNA (SHMAKOV et al., 2015; SCHINDELE et al., 2018), enabling new levels of control by operating at the RNA level. Cas13 can be used for targeting specific splicing isoforms (MAHAS et al., 2017) and knockdown of noncoding RNAs (ncRNAs) (WANG et al., 2016). Despite its importance, Cas13-containing systems do not allow transgene segregation since the cell must have the transgenic machinery to operate in the RNA.

Since CRISPR-Cas discovery and wide application in the last years, several new techniques have popped up. For instance, base and prime editors have been recently included in the CRISPR toolkit. Both are based on the use of a deactivated Cas (dCas), which is a catalytically impaired nuclease, whose purpose, along with the gRNA, is to solely guide another protein to the target, changing the DNA without creating DSBs (ANZALONE et al., 2019). Base editors act in a single-base level. As for prime editing, it mediates targeted insertions (up to $44 \mathrm{bp}$ ), deletions (up to $80 \mathrm{bp}$ ), and point mutations including all 12 possible base-to-base conversions (C:T, G:A, A:G, T:C, C:A, C:G, G:C, G:T, A:C, A:T, $\mathrm{T}: \mathrm{A}$, and $\mathrm{T}: \mathrm{G})$ without requiring $\mathrm{DSBs}$ or donor DNA templates (ANZALONE et al., 2019). These approaches not only represent the newest assets in the editing toolkit but also a step closer to the ideal goal of manipulating genomes, fastforwarding evolution in our favor, with minimal unwanted genome perturbation (ANZALONE et al., 2020).

One of the biggest advantages of CRISPRbased systems is that targeted and precise mutations can be achieved and passed on to the next generation independently from the transgenic cassette since the mutation and the exogenous DNA are usually located in different chromosomes (WOO et al., 2015; XU et al., 2015; ZHOU et al., 2015). The possibility of developing transgene-free plants carrying heritable mutations has a huge impact on cost and time length for generating biotechnology-mediated improved crops, besides broadening its accessibility by parties other than large companies (CHEN et al., 2001; FENG et al., 2014; SCHIML et al., 2014; BELHAJ et al., 2015; DING et al., 2016; OSAKABE et al., 2016).

Transgene-clean plants may also be generated by applying the CRISPR-Cas system as ribonucleoproteins (RNP) to act transiently in the cell, rather than being genetically integrated into the cell genome. In this strategy, nuclease mixed with gRNA is directly delivered to the plant cell, reducing the time spent to obtain non-GM plants (WOO et al., 2015; SVITASHEV et al., 2016; KIM et al., 2017; LIANG et al., 2017). These time-saving and non-GM advantages are especially valuable in perennial crops with a long generation time, clone-derived plants, in which segregation of the CRISPR-Cas locus is lengthy and impractical, respectively, and for directly edible crops such as horticultural species, due to public acceptance (KOLTUN et al., 2018).

\section{Next-generation plant breeding involving genome editing \\ CRISPR-Cas-mediated genome editing has} the potential to enable certain achievements in crop improvement and fasten plant breeding programs. Some of these applications are summarized in Figure 1. 
Figure 1. Practical applications of CRISPR-Cas in plant breeding.

Improving agronomic traits

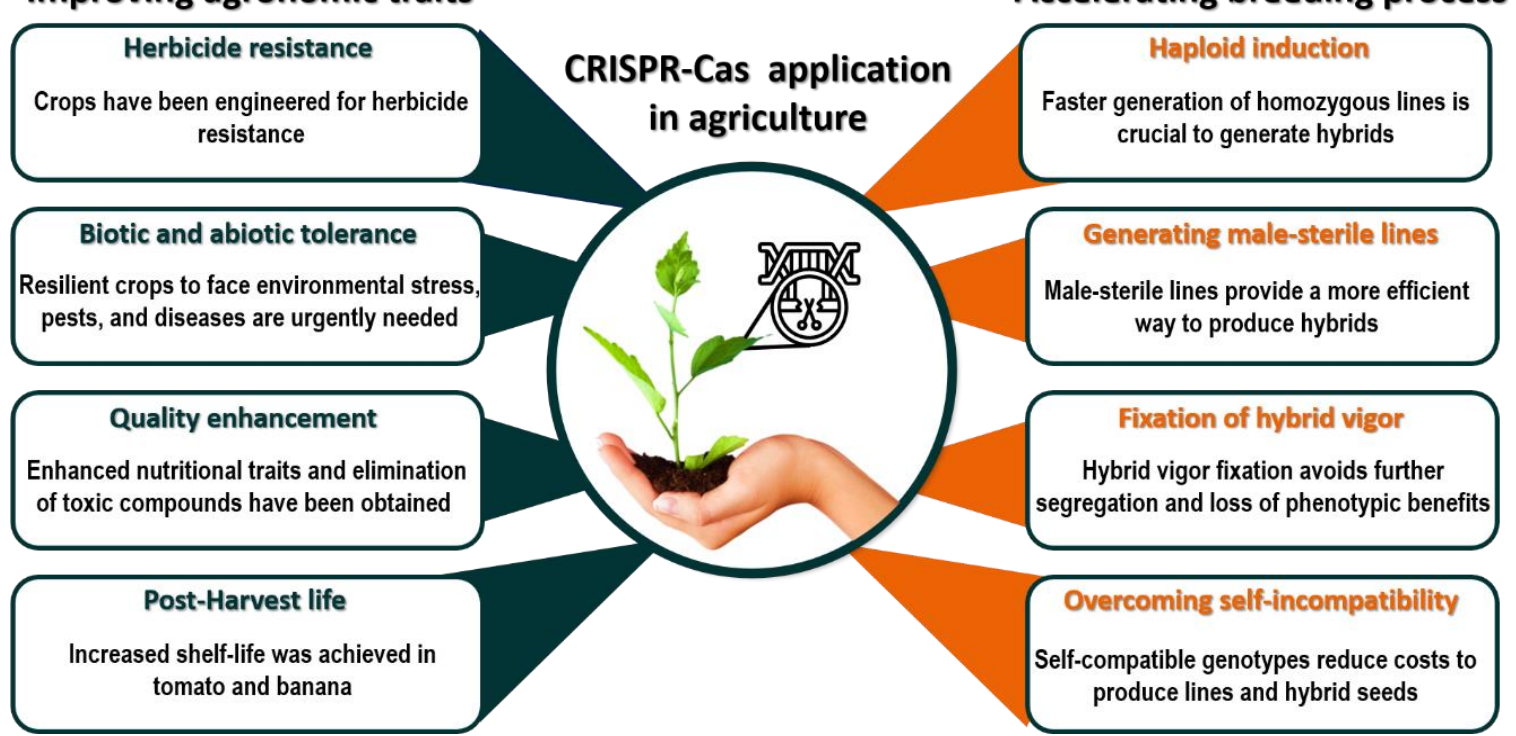

CRISPR-Cas induced mutations in crop improvement

\section{Herbicide resistance}

Weeds drastically hinder crop productivity globally. Herbicide-resistant genotypes were generated as an alternative to maintain high yield. The transgenic approach has been used for this matter. However, currently, there seems to be a shift to the CRISPR-Cas technique aiming for non-GMOs. Genome editing tools have already been applied for this purpose in some highly important crops, such as rice (LI et al., 2016; SUN et al., 2016; ZHANG et al., 2020a), soybean (LI et al., 2015), maize (JIANG et al., 2020), oilseed rape (WU et al., 2020), tomato, and potato (VEILLET et al., 2019).

The most common herbicide resistance pathway targeted by CRISPR-Cas has been the branched-chain amino acid biosynthesis, having acetolactate synthase (ALS) as the key enzyme. The mutation of ALS in specific amino acids results in resistance to herbicides such as sulfonylurea and imidazolinone. Herbicideresistant rice was obtained using the HR pathway, either by the introduction of multiple discrete point mutations in OsALS gene (SUN et al., 2016) or by prime editing, using a cytosine base editor to generate mutations in P171 and/or G628 codons of OsALS (ZHANG et al., 2020a). The prime editing strategy was also used to generate sulfonylurea herbicide-resistant maize (LI et al., 2020b), oilseed rape (WU et al., 2020), tomato, and potato (VEILLET et al., 2019).

Additionally, rice with resistance to auxinic herbicides, such as picloram 2,4dichlorophenoxyacetic acid (2,4-D), was successfully generated by partial deletion of the auxin signaling f-box OsAFB4 gene, which codes for a selective auxin receptor (GUO et al., 2021). Also in rice, two amino acids of the 5enolpyruvylshikimate-3-phosphate synthase (EPSPS) gene, involved in aromatic amino acid biosynthesis, were edited, leading to resistance to EPSPS-based herbicides, such as glyphosate. For that, two gRNAs were used to induce gene replacement by NHEJ, providing a DNA template containing the desired point mutations. Therefore, with directly joinable ends, NHEJ can accurately repair the CRISPR-Cas induced DSB. This strategy successfully generated rice plants resistant to EPSPS herbicides without using homologous recombination for gene swap (니 et al., 2016). It is worth noting that these approaches require precise modifications for the target enzyme to no longer bind to the harmful herbicide molecules, yet still be functional.

\section{Tolerance to abiotic and biotic stress}

Another application of the CRISPR-Cas toolkit is to develop genotypes with resistance or tolerance to biotic and abiotic stresses. Due to climate change, resilient crops adapted to nonideal environmental conditions are urgently 
needed. In this context, drought-tolerant maize plants were developed through $\mathrm{HR}$, introducing or swapping the promoter region of the ARGOS8 gene by the GOS2 promoter, containing droughtresponsive cis-elements. The ARGOS8 gene is a negative regulator of ethylene responses and its overexpression promotes cell expansion and/or division, mitigating yield loss by enhancing plant growth under drought stress (SHI et al., 2017). In this study, a native and stronger promoter within the maize genome was used to enhance its expression.

Climate change also affects pathogen-host interaction and may lead to higher disease incidence, which threatens crop yield. Thus, CRISPR-Cas may be used to generate diseaseresistant plants, mainly by silencing genes that negatively regulate defense pathways, shielding plants from pathogen attacks. Rice plants resistant to the fungus Magnaporthe oryzae were generated by a frameshift mutation in the gene OsERF922, which encodes an ethylene-responsive factor, a negative regulator of rice blast resistance (WANG et al., 2016). Similarly, maize plants resistant to Ustilago maydis were obtained through knockout of lipoxygenase3 (LOX3), another gene that negatively regulates fungal disease resistance (PATHI et al., 2020). In wheat, genes related to susceptibility to powdery mildew (Blumeriag aminis f. sp. tritici) were knocked out, including three homoeoalleles of mildew resistance locus gene (MLO) (WANG et al., 2014) and three homoeologous of enhanced disease resistance1 (TaEDR1) (ZHANG et al., 2017), enhancing wheat tolerance to the disease. Moreover, the CRISPR-Cas tool may also be used to create specific changes in genomes, such as single nucleotide polymorphism (SNP) replacement. Potato plants resistant to late blight, caused by Phytophthora infestans, were obtained by replacing a single base, $\mathrm{A}$ to $\mathrm{C}$, in the second exon of caffeoyl-CoA O-methyltransferase (StCCOAOMT) gene by HR (HEGDE et al., 2021).

In soybean, a CRISPR-Cas-based strategy was used to diversify plant innate immune system, enhancing disease resistance. This technique consisted of generating diversity on loci of the key defense family genes from the nucleotidebinding-site-leucine-rich-repeat (NBS-LRR) class, through gene rearrangements, resulting in new positive variants (NAGY et al., 2021). Another new emerging approach is based on engineering plant-associated microbiome not only to improve crop growth but also to increase pathogen resistance. Plant and microbiome are so intrinsically intertwined that the related microbiome is considered the second genome of plants (KUMAR; DUBEY, 2020). Furthermore, plant pathogens change the population of antagonistic microbes and, consequently, the plant immune responses, leading to pathogen control (SHELAKE et al., 2019). Thus the application of the CRISPR-Cas tool in synthetic biology has the potential to enhance plant resistance mechanisms against pathogens (CHAUDHARY et al., 2021).

\section{Quality and durability improvement}

Beyond yield, other traits are relevant in crop production. For example, grains with low amylose content have been widely used in textile and adhesives industries, besides presenting better eating and cooking quality. The enzyme granule-bound starch synthase I (GBSS I), encoded by the waxy $(W x)$ locus, is required for amylose synthesis and determines the amylose content of the endosperm. In waxy maize, homozygous recessive $W x$ alleles result in maize grains mostly composed of amylopectin (Ql et al., 2020a). Thus, the deletion of 4- and 6-kb of the waxy gene using two gRNAs successfully generated maize mutants with reduced amylopectin in the endosperm, with content comparable to those genotypes with homozygous recessive waxy locus (GAO et al., 2020). Similarly, the CRISPR-Cas targeted mutagenesis was used to generate waxy rice through the alteration of the $W x^{b}$ gene sequence using cytidine base editing (XU et al., 2021b).

Grain components that can lead to allergic reactions may also be manipulated using CRISPR-Cas. Gluten proteins present in wheat can trigger coeliac disease in sensible humans. The alfa-gliadin protein family is the main group associated with coeliac disease, being encoded by around 100 genes. Thus conventional breeding methods cannot substantially reduce this allergenic compound content (OZUNA et al., 2015). The CRISPR-Cas tool allowed to target conserved region of alpha-gliadin genes using two gRNAs to create indels that resulted in a reduction of $85 \%$ of gluten content in wheat grains (SÁNCHEZ-LEÓN et al., 2018). Likewise, in soybean grains, the presence of raffinose oligosaccharides family (RFOs) hinders the soybean-based feed digestion by monogastric animals (HOU et al., 2009). Le et al. (2020) used two gRNAs to knockout two soybean galactinol 
synthase genes (GOLS), GmGOLS1A, and its homeolog GmGOLS1B, reducing the stachyose content by $35 \%$, the most predominant RFO in soybean seeds. Furthermore, the vicilin-like glycoprotein Gly $\mathrm{m} \mathrm{Bd} 28 \mathrm{~K}$ and the oil bodyassociated protein Gly $\mathrm{m} \mathrm{Bd} 30 \mathrm{~K}$ are reported as major allergens in soybean. Therefore, in order to favor soybean consumption by humans, genes that encode both proteins were edited by CRISPR-Cas, generating grains free of these allergenic compounds (SUGANO et al., 2020).

Additionally, CRISPR-Cas may be used to increase food quality. For instance, soybean and peanut grains with increased oleic acid content were generated via CRISPR-Cas-induced indels in the fatty acid desaturase (FAD2) gene, which encodes one of the enzymes responsible for converting oleic to linoleic acid (AL AMIN et al., 2019; YUAN et al., 2019). In tomato, lycopene content was enhanced using a multiplex system to knock down six genes involved in the carotenoid metabolic pathway, preventing the conversion of lycopene to beta and alphacarotene (LI et al., 2018). In rice, increased carotenoids levels were achieved by the introduction of a $5.2 \mathrm{~kb}$ cassette for carotenoids biosynthesis in two genomic safe harbors by HR, with no off-target effect in mutated plants (DONG et al., 2020).

Food shelf-life and storage can also be enhanced by CRISPR-Cas. In tomato, several genes are well-known to have long-shelf-life properties; however, their introduction by traditional breeding led to loss in organoleptic quality (CASALS et al., 2011). Therefore, the CRISPR-Cas system was used for targeted mutation without off-target effects. Yu et al. (2017) obtained tomato fruits with a longer shelflife by introducing the known monogenic mutation alcobaca (alc), an allele of the nonripening gene (NOR), using HR (YU et al., 2017). Interestingly, tomato germplasm containing the natural alc mutation is correlated with small fruit size probably due to gene drag in the selection to extend shelf-life (CASALS et al., 2012). Thereby, CRISPR-Cas is proven to be a precious asset in targeted mutation without some drawbacks of conventional breeding. CRISPR-Cas9 was also applied to edit aminocyclopropane-1-carboxylate oxidase 1 gene (MaACO1), enhancing banana shelf-life (HU et al., 2021). All of these examples are crucial improvements for the commercialization of such perishable products.

\section{Application of CRISPR-Cas to accelerate breeding processes}

Haploid induction

In crop breeding aiming to generate hybrids, obtaining homozygous lines is the first step. However, this may be a time-consuming and laborious process. Double haploid technology via in vivo haploid induction is generally applied to accelerate this step in maize and other crops. In this case, the gene-editing approach may be used to produce haploid inducer lines. In maize and rice, CRISPR-Cas induced mutations in a spermspecific phospholipase, resulting in defective male gametophytes and triggering maternal haploid induction (LIU et al., 2017; YAO et al., 2018).

New emerging strategies for haploid induction, called haploid induction editing (HIEdit) (KELLIHER et al., 2019) and haploid inducermediated genome editing (IMGE) (WANG et al., 2019a), consist in modifying an elite genotype via pollination of commercial backgrounds with a haploid-inducing line carrying a CRISPR-Cas cassette targeting a desired agronomic trait. Both HI-Edit and IMGE have the potential to be widely adopted to generate double haploids in several crops, replacing the burdensome and lengthy introgression process and generating double haploid lines with desired traits in only two generations (WANG et al., 2019a).

Although double haploid lines generated by CRISPR-Cas represent valuable advantages, the identification of edited cells is still a challenge. To overcome this obstacle some techniques were developed. For instance, in ViMeBox, a visible marker driven by a tissue-specific promoter is introduced into CRISPR-Cas expression vectors. The ViMeBox tool may also be combined with HIEdit (KELLIHER et al., 2019) and IMGE (WANG et al., 2019a), once ViMeBox allows the easy identification of diploids by exhibiting red visible embryos, increasing the efficiency of the process (XU et al., 2021a).

\section{Generating male-sterile lines}

Hybrids are commonly used in agriculture due to heterosis or hybrid vigor associated with higher yield. Hybrid seeds are produced by crossing lines, wherein each parent donates either the male or female gamete. In crops such as wheat, rice, and maize, it is preferable to use male-sterile maternal lines to avoid contamination with female self-fertilized seeds. 
Although male-sterile lines have been reported in several crops, generating them through conventional breeding requires a considerable amount of labor and time. Therefore, gene editing by CRISPR-Cas may be a faster alternative to obtain male-sterile lines.

For instance, in maize, CRISPR-Cas was used to delete an essential catalytic region of male sterility 26 (MS26) gene, translating a nonfunctional member of cytochrome P450 monooxygenase family and generating complete male-sterile plants (Ql et al., 2020b). Similarly, disruption of TaNP1 genes, which encodes a putative glucose-methanol-choline oxidoreductase, resulted in complete male sterility in wheat (LI et al., 2020a). Multiplexdirected mutations driven by CRISPR-Cas are especially valuable in polyploid crops, which present redundant alleles, being very difficult to be generated/or gathered by other processes from traditional crop improvement.

\section{Fixation of hybrid vigor}

Hybrids are widely used in crop breeding aiming for heterosis. However, the phenotypic superiority achieved in $F_{1}$ is lost in further crosses. Clonal propagation of hybrid $F_{1}$ seeds may keep heterosis benefits and facilitate hybrid seed production. This purpose can be achieved by apomixis, an asexual reproductive pathway that produces seeds without fertilization (WANG et al., 2019b). In rice, $F_{1}$ heterozygosity was fixated via CRISPR-Cas by editing the meiotic genes REC8, $P A I R 1$, and OSD1 simultaneously, creating the socalled Mitosis instead of Meiosis (MiMe) genotype and enabling the production of diploid gametes and tetraploid seeds (WANG et al., 2019b). In a further step, besides the multiplex approach with the three mentioned genes, Wang and collaborators simultaneously muted the haploid induction gene matrilineal gene (MTL). The MiMe plants with paternal genome eliminated by the mutated MTL produced selffertilized $F_{1}$ hybrids and clonal seeds with the same ploidy and heterozygous genotype (WANG et al., 2019b). Although using apomixis induced by CRISPR-Cas is a tremendously advantageous possibility to fix hybrid vigor, further studies are needed for this strategy to be widely applied in hybrid seed production.

\section{Overcoming self-incompatibility}

In flowering plants, self-incompatibility prevents self-fertilization by discriminating self and outcross pollen. This phenomenon occurs in several important crops, such as canola, potato, pome, coffee, olive, among others. This mechanism is often controlled by a single multiallelic locus, called S-locus (MUÑOZ-SANZ et al., 2020). In Solanaceae, such as potato and tomato, the mutation of S-RNase gene, a codominant gene responsible for gametophytic selfincompatibility, resulted in self-compatible lines (QIN et al., 2018; ENCISO-RODRIGUEZ et al., 2019). In cabbage and oilseed rape, the sporophytic self-incompatibility was overcome by knockout of $\mathrm{M}$-locus protein kinase and $\mathrm{S}$ receptor kinase, respectively, also using CRISPRCas (CHEN et al., 2019a; MA et al., 2019). Creating self-compatible genotypes by CRISPRCas enables the generation of inbred lines, as well as hybrid seeds, in a cheaper and faster way. In addition, for fruit production, the generation of self-compatible genotypes may facilitate the pollination process by dispensing the cultivation of pollination plants in orchards (MA; QU, 2019).

\section{Regulatory issues - raising hurdles for CRISPR crops}

The regulations surrounding the new plant breeding technologies (NBTs), including CRISPR-Cas, are still being debated and established worldwide, due to their unanticipated possibilities (recently reviewed in TURNBULL et al., 2021). Policymakers are defining, among other aspects, whether or not CRISPR-edited plants fall into special regulatory regimes as GMOs (PODEVIN et al., 2012). Recently, many major countries have released updated regulatory frameworks, or are close to doing so. Whereas others are yet to release any formal decisions (SCHEBEN; EDWARDS, 2018; LASSOUED et al., 2020). It seems that countries are fiercely debating the risks to health and the environment and cautiously considering all the implications of different policymaking options to their economy.

Law-making parties are taking into account either a process-based or a productbased approach to regulating genome-edited crops and derived products. For instance, the European Union and Russia assess the process, while the United States, Canada, Argentina, and Brazil analyze the product, irrespective of the technique used to obtain it (CTNBIO, 2018; KULUEV et al., 2019; GAO, 2021). Although it is not unanimous, many researchers strongly argue that transgene-free edited crops do not pose 
unreasonable risk, being indistinguishable from natural mutants; therefore, should not be subjected to any special safety assessment (KULUEV et al., 2019; VAN EENENNAAM et al., 2019; ZHANG et al., 2020b). Strict regulation and social rejection - converging aspects - concerning genome-edited crops could undermine all major benefits brought by NBTs and hugely and negatively affect the evolution of the field (LASSOUED et al., 2019).

The edition via CRISPR-Cas fits into the site-directed nucleases (SDN) framework. In Brazil, organisms containing mutations produced by SDN1 systems (rejoin of broken DNA ends by the error-prone NHEJ leading to small indels) do not qualify as GMOs since the Biosafety Law excludes products obtained by mutagenesis from the GMO scope, as they simulate natural mechanisms. SDN2 genome editing systems (repair via homologous recombination by adding a relatively short DNA fragment causing slight alteration), are analyzed on a case-by-case basis by the Brazilian legislation, mainly taking into account the presence of foreign DNA. Finally, SDN3 systems (repair via homologous recombination by introducing a large DNA fragment) normally fit as GMOs and can be evaluated individually depending on the origin of the DNA used (exogenous or not) (SPRINK et al., 2016; CTNBIO, 2018).

In the USA, more than 100 genomeedited plant varieties have been designated as not regulated and have freely entered market channels, including oleic acid-enriched soybean (DO et al., 2019), high-oil content camelina (WALTZ, 2018), and powdery mildew resistant wheat (WANG et al., 2014). In 2018, the Brazilian legislation judged a high-amylopectin (waxy) maize as non-GMO. It is worth noting that new varieties undergo extensive field evaluations according to traditional breeding practices. On the other hand, the European Union has decided that organisms with an edited genome should be subjected to the same strict regulations as transgenics, even though there is no consensus among the countries that compose it.

Despite some achievements, nonscientific political decisions have been made in the law-defining process regarding NBTs (URNOV et al., 2018), which hampers the advancement of agriculture around the world. Deregulation of products generated via NBTs implies cheaper and accessible technology for public institutions and small companies, diversifying the participants in technological innovation (FRIEDRICHS et al., 2019). However, if a restrictive regulatory approach is adopted and treats edited plants as GM crops, it would create huge financial burdens that only large multinational companies could afford, excluding universities, nonprofits, and other small companies.

Overall, the conflicting regulations on genome editing will have consequences for international trade that are yet to be determined, but that will probably lead to commercial impediments, decreased profits, and difficulty enforcing policies. Traceability is a major problem. Depending on the case, it is impossible to detect whether a DNA mutation resulted from natural evolution or CRISPR manipulation (GAO, 2018).

Another issue to be considered is product labeling. Some regulatory approaches have appeared regarding labeling the editedplants-derived products as bioengineered (VAN EENENNAAM et al., 2019). High caution should be taken in this matter to avoid past mistakes, such as the backlash once seen with GMOs, rising fake news and myths around these products. This would lead to even more delays to gene-edited food integration into the market, and be very detrimental to research and applications in this field.

Since genome editing is a highly complex molecular toolbox, a suitable sciencebased regulatory approach should be built to embrace its complexity and to cope with future advances, in order to decide whether some of them require special legal regulation (HUANG et al., 2016; CHEN; GAO, 2020; LASSOUED et al., 2020; MACNAGHTEN; HABETS, 2020). More effort is needed to promote knowledge-based discussions aiming to increase public and regulatory authorities' awareness and to move towards reasonable interpretations and decisions (reviewed in DUENSING et al., 2018). A very wellthought-through approach balancing precaution and innovation will enable the use of CRISPR-Cas to bring innovative solutions to agriculture.

\section{Challenges and future perspectives}

Even though the CRISPR-Cas system is a highly promising approach at the forefront of scientific knowledge and applicability, some challenges still need to be addressed in the years to come. Since most genome editing techniques depend on an initial generation of transgenic plants, one of the major drawbacks is the tissue 
culture step. Most crops still have low efficiency of transformation and regeneration and the protocols used are usually genotype-dependent. In most cases, the transformation-prone genotypes are not the elite ones, requiring an extra effort to later cross the plants (ATKINS; VOYTAS, 2020).

Several groups have been working on strategies to overcome bottlenecks in plant gene editing (reviewed in ATKINS; VOYTAS, 2020). A brilliant alternative to traditional regeneration techniques is somatic reprogramming, in which morphogenic regulators are expressed to determine cell fate. Embryo regeneration from somatic tissue has already been achieved with high efficiency using a developmental factor associated with somatic embryogenesis ( $B A B Y B O O M ; B B M)$ and a meristem maintenance transcription factor (WUSCHEL; WUS) (LOWE et al., 2016, 2018; MOOKKAN et al., 2017). Other genes such as growth-regulating factors (GRFs), grf-interacting factors (GIFs), and GRF-GIF chimeras have also been used to improve the regeneration efficiency in monocot and dicot plants (DEBERNARDI et al., 2020; KONG et al., 2020).

Another challenge in genome editing is to improve HR efficiency. Some strategies have been developed, such as the use of geminivirus constructs (BALTES et al., 2014), in planta gene targeting system (FAUSER et al., 2012), cell synchronization in $\mathrm{S} / \mathrm{G} 2$, and inhibition of cellular NHEJ repair (LIN et al., 2014; GUTSCHNER et al., 2016; HOWDEN et al., 2016). Another work-inprogress technique to increase DNA insertion efficiency and size of donor DNA is the transposon-associated CRISPR-Cas system, which allows site-targeted DNA insertion without having to rely on host-cell repair machinery (MA et al., 2021).

As for future prospects, besides overcoming the aforementioned obstacles, further enhancement of CRISPR-Cas efficiency is needed, as well as a massive effort to broaden its applicability to more crops. Excitingly, new approaches have arisen quite frequently. For instance, CRISPR-Cas genome editing tools now enable rearrangement of large chromosomal fragments, which can be used to break genetic linkages with deleterious genes or to generate linkages between favorable genes, and applied as a tool for synthetic plant chromosomes (RÖNSPIES; SCHINDELE; PUCHTA, 2021).
Here we have presented the CRISPR-Cas technique from its most basic technique to the most advanced and recent ones, along with several practical applications. It is undeniable that genome editing is a revolutionizing tool in many fields, including agriculture. It has the potential to accelerate the development of elite genotypes with urgently needed characteristics ranging from tolerance to stresses to enhanced nutritional value, besides opening up a new era in crop breeding.

\section{References}

AL AMIN, N.; AHMAD, N.; WU, N.; PU, X.; MA, T.; DU, Y.; BO, X.; WANG, N.; SHARIF, R.; WANG, P. CRISPR-Cas9 mediated targeted disruption of FAD2-2 microsomal omega-6 desaturase in soybean (Glycine max.L). BMC Biotechnology, v.19, n.9, p.1-10, 2019. https://doi.org/10.1186/s12896-019-0501-2

ANAMI, S.; NJUGUNA, E.; COUSSENS, G.; AESAERT, S.; VAN LIJSEBETTENS, M. Higher plant transformation: principles and molecular tools. The International journal of developmental biology, v.57, n.6-8, p.483-494, 2013. https://doi.org/10.1387/ijdb.130232mv

ANDERS, C.; NIEWOEHNER, O.; DUERST, A.; JINEK, $M$. Structural basis of PAM-dependent target DNA recognition by the Cas9 endonuclease. Nature, v.513, p.7519, p.569-573, 2014. https://doi.org/10.1038/nature13579

ANZALONE, A. V.; RANDOLPH, P. B.; DAVIS, J. R.; SOUSA, A. A.; KOBLAN, L. W.; LEVY, J. M.; CHEN, P. J.; WILSON, C.; NEWBY, G. A.; RAGURAM, A.; LIU, D. R. Search-and-replace genome editing without double-strand breaks or donor DNA. Nature, v.576, p.149-157, 2019. https://doi.org/10.1038/s41586-019-1711-4

ANZALONE, A. V; KOBLAN, L. W.; LIU, D. R. Genome editing with CRISPR-Cas nucleases, base editors, transposases and prime editors. Nature Biotechnology, v.38, n.7, p.824-844, 2020. https://doi.org/10.1038/s41587-020-0561-9

ATKINS, P. A.; VOYTAS, D. F. Overcoming bottlenecks in plant gene editing. Current Opinion in Plant Biology, v.54, p.79-84, 2020. https://doi.org/10.1016/j.pbi.2020.01.002

BALTES, N. J.; GIL-HUMANES, J.; CERMAK, T.; 
ATKINS, P. A.; VOYTAS, D. F. DNA replicons for plant genome engineering. Plant Cell, v.26, n.1, p.151-163, 2014. https://doi.org/10.1105/tpc.113.119792

BELHAJ, K.; CHAPARRO-GARCIA, A.; KAMOUN, S.; PATRON, N. J.; NEKRASOV, V. Editing plant genomes with CRISPR/Cas9. Current Opinion in Biotechnology, v.32, p.76-84, 2015. https://doi.org/10.1016/j.copbio.2014.11.007

BRADFORD, K. J.; VAN DEYNZE, A.; GUTTERSON, N.; PARROTT, W.; STRAUSS, S. H. Regulating transgenic crops sensibly: lessons from plant breeding, biotechnology and genomics. Nature Biotechnology, v.23, n.4, p.439-444, 2005. https://doi.org/10.1038/nbt1084

CASALS, J.; CEBOLLA-CORNEJO, J.; ROSELLÓ, S.; BELTRÁN, J.; CASAÑAS, F.; NUEZ, F. Long-term postharvest aroma evolution of tomatoes with the alcobaça (alc) mutation. European Food Research and Technology, v.233, n.2, p.331-342, 2011. https://doi.org/10.1007/s00217-011-1517$\underline{6}$

CHAUDHARY, T.; GERA, R.; SHUKLA1, P. Emerging molecular tools for engineering phytomicrobiome. Indian Journal of Microbiology, v.61, n.2, p.116-124, 2021. hhttps://doi.org/10.1007/s12088-020-00915-1

CHEN, F.; DAHAL, P.; BRADFORD, K. Two tomato expansin genes show divergent expression and localization in embryos during seed development and germination. Plant Physiology, v.127, Nov. p.928-936, 2001. https://doi.org/10.1104/pp.127.3.928

CHEN, F.; YANG, Y.; LI, B.; LIU, Z.; KHAN, F.; ZHANG, T.; ZHOU, G.; TU, J.; SHEN, J.; YI, B.; FU, T.; DAI, C.; MA, C. Functional analysis of $m$-locus protein kinase revealed a novel regulatory mechanism of self-incompatibility in Brassica napus L. International Journal of Molecular Sciences, v.20, n.13, 2019a. https://doi.org/10.3390/ijms20133303

CHEN, K.; GAO, C. Genome-edited crops: how to move them from laboratory to market. Front. Agr. Sci. Eng., v.7, n.2, p.181-187, 2020. https://doi.org/10.15302/J-FASE-2020332

CHEN, K.; WANG, Y.; ZHANG, R.; ZHANG, H.; GAO,
C. CRISPR/Cas genome editing and precision plant breeding in agriculture. Annual Review of Plant Biology, v.70, n.1, p.667-697, 2019b. https://doi.org/10.1146/annurev-arplant$\underline{050718-100049}$

CTNBIO. Resolução Normativa $n^{\circ}$ 16, de 15 de janeiro de 2018. Available in: http://ctnbio.mctic.gov.br/resolucoesnormativas/-

/asset_publisher/OgW431Rs9dQ6/content/resol ucao-normativa-n ${ }^{\circ}$-16-de-15-de-janeiro-de-2018. Accessed in: April, 2021.

DEBERNARDI, J. M.; TRICOLI, D. M.; ERCOLI, M. F.; HAYTA, S.; RONALD, P.; PALATNIK, J. F.; DUBCOVSKY, J. A GRF-GIF chimeric protein improves the regeneration efficiency of transgenic plants. Nature Biotechnology, v.38, n.11, p.1274-1279, 2020. https://doi.org/10.1038/s41587-020-0703-0

DING, Y.; LI, H.; CHEN, L.-L.; XIE, K. Recent advances in genome editing using CRISPR/Cas9. Frontiers in Plant Science, v.7, p.1-12, 2016. https://doi.org/10.3389/fpls.2016.00703

DO, P. T.; NGUYEN, C. X.; BUI, H. T.; TRAN, L. T. N.; STACEY, G.; GILLMAN, J. D.; ZHANG, Z. J.; STACEY, $M$. G. Demonstration of highly efficient dual gRNA CRISPR/Cas9 editing of the homeologous GmFAD2-1A and GmFAD2-1B genes to yield a high oleic, low linoleic and $\alpha$-linolenic acid phenotype in soybean. BMC Plant Biology, v. 19, p.311, 2019. https://doi.org/10.1186/s12870$\underline{019-1906-8}$

DONG, O. X.; YU, S.; JAIN, R.; ZHANG, N.; DUONG, P. Q.; BUTLER, C.; LI, Y.; LIPZEN, A.; MARTIN, J. A.; BARRY, K. W.; SCHMUTZ, J.; TIAN, L.; RONALD, P. C. Marker-free carotenoid-enriched rice generated through targeted gene insertion using CRISPR-Cas9. Nature Communications, v.11, n.1, p.1-10, 2020. https://doi.org/10.1038/s41467020-14981-y

DOUDNA, J. A.; CHARPENTIER, E. The new frontier of genome engineering with CRISPRCas9. Science, v.346, n.6213, p.12580961258096, 2014. https://doi.org/10.1126/science.1258096

DUENSING, N.; SPRINK, T.; PARROTT, W. A.; FEDOROVA, M.; LEMA, M. A.; WOLT, J. D.; 
BARTSCH, D. Novel features and considerations for era and regulation of crops produced by genome editing. Frontiers in Bioengineering and Biotechnology, v.6, p.79, 2018. https://doi.org/10.3389/fbioe.2018.00079

ENCISO-RODRIGUEZ, F.; MANRIQUECARPINTERO, N. C.; NADAKUDUTI, S. S.; BUELL, C. R.; ZARKA, D.; DOUCHES, D. Overcoming selfincompatibility in diploid potato using CRISPRCas9. Frontiers in Plant Science, v.10, n. April, p.1-12, 2019.

https://doi.org/10.3389/fpls.2019.00376

FAO. The future of food and agriculture: Trends and challenges. 2017.

FAUSER, F.; ROTH, N.; PACHER, M.; ILG, G.; SÁNCHEZ-FERNÁNDEZ, R.; BIESGEN, C.; PUCHTA, $\mathrm{H}$. In planta gene targeting. Proceedings of the National Academy of Sciences, v.109, n.19, p.7535-7540, 2012.

https://doi.org/10.1073/pnas.1202191109

FENG, Z.; MAO, Y.; XU, N.; ZHANG, B.; WEI, P.; YANG, D. L.; WANG, Z.; ZHANG, Z.; ZHENG, R.; YANG, L.; ZENG, L.; LIU, X.; ZHU, J. K. Multigeneration analysis reveals the inheritance, specificity, and patterns of CRISPR/Cas-induced gene modifications in Arabidopsis. Proc Natl Acad Sci U S A, v.111, n.12, p.4632-4637, 2014. https://doi.org/10.1073/pnas.1400822111

FENG, Z.; ZHANG, B.; DING, W.; LIU, X.; YANG, D.L.; WEI, P.; CAO, F.; ZHU, S.; ZHANG, F.; MAO, Y.; $\mathrm{ZHU}$, J.-K. Efficient genome editing in plants using a CRISPR/Cas system. Cell Research, v.23, n.10, p.1229-1232, 2013. https://doi.org/10.1038/cr.2013.114

FRIEDRICHS, S.; TAKASU, Y.; KEARNS, P.; DAGALLIER, B.; OSHIMA, R.; SCHOFIELD, J.; MOREDDU, C. Policy considerations regarding genome editing. Trends in biotechnology, v.37, n.10, p.1029-1032. 2019. https://doi.org/10.1016/i.tibtech.2019.05.005

FURUHATA, Y.; KATO, Y. Asymmetric roles of two histidine residues in Streptococcus Pyogenes Cas9 catalytic domains upon chemical rescue. Biochemistry, v.60, n.3, p.194-200, 26 jan. 2021. https://doi.org/10.1021/acs.biochem.0c00766

GAO, C. The future of CRISPR technologies in agriculture. Nature Reviews Molecular Cell Biology, v.19, n.5, p.275-276, 2018. https://doi.org/10.1038/nrm.2018.2

GAO, C. Genome engineering for crop improvement and future agriculture. Cell, v.184, n.6, p.1621-1635, 2021.

https://doi.org/10.1016/i.cell.2021.01.005

GAO, H.; GADLAGE, M. J.; LAFITTE, H. R.; LENDERTS, B.; YANG, M.; SCHRODER, M.; FARRELL, J.; SNOPEK, K.; PETERSON, D.; FEIGENBUTZ, L.; JONES, S.; ST CLAIR, G.; RAHE, M.; SANYOUR-DOYEL, N.; PENG, C.; WANG, L.; YOUNG, J. K.; BEATTY, M.; DAHLKE, B.; HAZEBROEK, J.; GREENE, T. W.; CIGAN, A. M.; CHILCOAT, N. D.; MEELEY, R. B. Superior field performance of waxy corn engineered using CRISPR-Cas9. Nature Biotechnology, v.38, n.5, p.579-581, 2020.

https://doi.org/10.1038/s41587-020-0444-0

GORBUNOVA, V.; LEVY, A. A. Non-homologous DNA end joining in plant cells is associated with deletions and filler DNA insertionsNucleic Acids Research. Nucleic Acid Research, v.25, n.22, p.4650-4657, 1997.

https://doi.org/10.1093/nar/25.22.4650

GUO, F.; HUANG, Y.; QI, P.; LIAN, G.; HU, X.; HAN, N.; WANG, J.; ZHU, M.; QIAN, Q.; BIAN, H. Functional analysis of auxin receptor OsTIR1/OsAFB family members in rice grain yield, tillering, plant height, root system, germination, and auxinic herbicide resistance. New Phytologist, v.229, n.5, p.2676-2692, 2021. https://doi.org/10.1111/nph.17061

GUTSCHNER, T.; HAEMMERLE, M.; GENOVESE, G.; DRAETTA, G. F.; CHIN, L. Post-translational regulation of Cas9 during $\mathrm{G} 1$ enhances homologydirected repair. Cell Reports, v.14, n.6, p.15551566, 16 fev. 2016. https://doi.org/10.1016/i.celrep.2016.01.019

HE, Y.; ZHAO, Y. Technological breakthroughs in generating transgene-free and genetically stable CRISPR-edited plants. aBIOTECH, v.1, n.1, p.8896, 2020. https://doi.org/10.1007/s42994-01900013-x

HEGDE, N.; JOSHI, S.; SONI, N.; KUSHALAPPA, A. $C$. The caffeoyl-CoA O-methyltransferase gene SNP replacement in Russet Burbank potato 
variety enhances late blight resistance through cell wall reinforcement. Plant Cell Reports, v.40, n.1, p.237-254, 2021. https://doi.org/10.1007/s00299-020-02629-6

HOLME, I. B.; GREGERSEN, P. L.; BRINCHPEDERSEN, $\mathrm{H}$. Induced genetic variation in crop plants by random or targeted mutagenesis: convergence and differences. Frontiers in Plant Science, v.10, p.1468, 2019. https://doi.org/10.3389/fpls.2019.01468

HOU, A.; CHEN, P.; SHI, A.; ZHANG, B.; WANG, Y.J. Sugar Variation in Soybean Seed Assessed with a Rapid Extraction and Quantification Method. International Journal of Agronomy, v. 2009, p. 484571, 2009. https://doi.org/10.1155/2009/484571

HOWDEN, S. E.; MCCOLL, B.; GLASER, A.; VADOLAS, J.; PETROU, S.; LITTLE, M. H.; ELEFANTY, A. G.; STANLEY, E. G. A Cas9 variant for efficient generation of indel-free knockin or genecorrected human pluripotent stem cells. Stem Cell Reports, v.7, n.3, p.508-517, 2016. https://doi.org/10.1016/j.stemcr.2016.07.001

HU, C.; SHENG, O.; DENG, G.; HE, W.; DONG, T.; YANG, Q.; DOU, T.; LI, C.; GAO, H.; LIU, S.; YI, G.; $\mathrm{BI}, \mathrm{F}$. CRISPR/Cas9-mediated genome editing of MaACO1 (aminocyclopropane-1-carboxylate oxidase 1) promotes the shelf life of banana fruit. Plant Biotechnology Journal, v.19, p.654-656, 2021. https://doi.org/10.1111/pbi.13534

HUANG, S.; WEIGEL, D.; BEACHY, R. N.; LI, J. A proposed regulatory framework for genomeedited crops. Nature Genetics, v. 48, n.2, p.109111, 2016. https://doi.org/10.1038/ng.3484

HUANG, T. K.; PUCHTA, H. CRISPR/Cas-mediated gene targeting in plants: finally a turn for the better for homologous recombination. Plant Cell Reports, v.38, n.4, p.443-453, 2019. https://doi.org/10.1007/s00299-019-02379-0

JIANG, Y. Y.; CHAI, Y. P.; LU, M. H.; HAN, X. L.; LIN, Q.; ZHANG, Y.; ZHANG, Q.; ZHOU, Y.; WANG, X. C.; GAO, C.; CHEN, Q. J. Prime editing efficiently generates W542L and S621I double mutations in two ALS genes in maize. Genome Biology, v.21, p.257, 2020. https://doi.org/10.1186/s13059020-02170-5
JINEK, M.; CHYLINSKI, K.; FONFARA, I.; HAUER, M.; DOUDNA, J. A.; CHARPENTIER, E. A programmable dual-RNA-guided DNA endonuclease in adaptive bacterial immunity. Science, v.337, p.816-822, 2012. doi: https://doi.org/10.1126/science.1225829

KATREKAR, D.; CHEN, G.; MELUZZI, D.; GANESH, A.; WORLIKAR, A.; SHIH, Y.-R.; VARGHESE, S.; MALI, P. In vivo RNA editing of point mutations via RNA-guided adenosine deaminases. Nature Methods, v.16, n.3, p.239-242, 2019. https://doi.org/10.1038/s41592-019-0323-0

KELLIHER, T.; STARR, D.; SU, X.; TANG, G.; CHEN, Z.; CARTER, J.; WITTICH, P. E.; DONG, S.; GREEN, J.; BURCH, E.; MCCUISTON, J.; GU, W.; SUN, Y.; STREBE, T.; ROBERTS, J.; BATE, N. J.; QUE, Q. Onestep genome editing of elite crop germplasm during haploid induction. Nature Biotechnology, v.37, n.3, p.287-292, 2019. https://doi.org/10.1038/s41587-019-0038-x

KIM, H.; KIM, S.-T.; RYU, J.; KANG, B.-C.; KIM, J.-S.; KIM, S.-G. CRISPR/Cpf1-mediated DNA-free plant genome editing. Nature Communications, v.8, p.14406, 2017.

https://doi.org/10.1038/ncomms14406

KOLTUN, A.; ERPEN-DALLA CORTE, L.; MERTZHENNING, L.; GONÇALVES, L. Genetic improvement of horticultural crops mediated by CRISPR/Cas: a new horizon of possibilities. Horticultura Brasileira, v.36, n.3, p.290-298, 2018. https://doi.org/10.1590/s0102053620180302

KONG, J.; MARTIN-ORTIGOSA, S.; FINER, J.; ORCHARD, N.; GUNADI, A.; BATTS, L. A.; THAKARE, D.; RUSH, B.; SCHMITZ, O.; STUIVER, M.; OLHOFT, P.; PACHECO-VILLALOBOS, D. Overexpression of the transcription factor growth-regulating factor5 improves transformation of dicot and monocot species. Frontiers in Plant Science, v.11, p.1-15, 2020. https://doi.org/10.3389/fpls.2020.572319

KULUEV, B. R.; GUMEROVA, G. R.; MIKHAYLOVA, E. V.; GERASHCHENKOV, G. A.; ROZHNOVA, N. A.; VERSHININA, Z. R.; KHYAZEV, A. V.; T., M. R.; BAYMIEV, A. K.; BAYMIEV, A. K.; CHEMERIS, A. V. Delivery of CRISPR/Cas components into higher plant cells for genome editing. Russian Journal of Plant Physiology, v.66, n.5, p.694-706, 2019. 
https://doi.org/10.1134/S102144371905011X

KUMAR, A.; DUBEY, A. Rhizosphere microbiome: engineering bacterial competitiveness for enhancing crop production. Journal of Advanced Research, v.24, p.337-352, 2020. https://doi.org/10.1016/j.jare.2020.04.014

LASSOUED, R.; MACALL, D. M.; HESSELN, H.; PHILLIPS, P. W. B.; SMYTH, S. J. Benefits of genome-edited crops: expert opinion. Transgenic Research, v.28, n.2, p.247-256, 2019. https://doi.org/10.1007/s11248-019-00118-5

LASSOUED, R.; MACALL, D. M.; SMYTH, S. J.; PHILLIPS, P. W. B.; HESSELN, H. How should we regulate products of new breeding techniques? Opinion of surveyed experts in plant biotechnology. Biotechnology Reports, v.26, p.e00460, 2020. https://doi.org/10.1016/i.btre.2020.e00460

LE, H.; NGUYEN, N. H.; TA, D. T.; LE, T. N. T.; BUI, T. P.; LE, N. T.; NGUYEN, C. X.; ROLLETSCHEK, H.; STACEY, G.; STACEY, M. G.; PHAM, N. B.; DO, P. T.; CHU, H. H. CRISPR/Cas9-mediated knockout of galactinol synthase-encoding genes reduces raffinose family oligosaccharide levels in soybean seeds. Frontiers in Plant Science, v.11, p.1-13, 2020. https://doi.org/10.3389/fpls.2020.612942

LI, J.; MENG, X.; ZONG, Y.; CHEN, K.; ZHANG, H.; LIU, J.; LI, J.; GAO, C. Gene replacements and insertions in rice by intron targeting using CRISPRCas9. Nature Plants, v.2, p.16139, 2016. https://doi.org/10.1038/nplants.2016.139

LI, J.; WANG, Z.; HE, G.; MA, L.; DENG, X. W. CRISPR/Cas9-mediated disruption of TaNP1 genes results in complete male sterility in bread wheat. Journal of Genetics and Genomics, v.47, n.20, n.5, p.263-272, 2020a. https://doi.org/10.1016/i.jgg.2020.05.004

LI, X.; WANG, Y.; CHEN, S.; TIAN, H.; FU, D.; ZHU, B.; LUO, Y.; ZHU, H. Lycopene is enriched in tomato fruit by CRISPR/Cas9-mediated multiplex genome editing. Frontiers in Plant Science, v.9, p.1-12, 2018.

https://doi.org/10.3389/fpls.2018.00559

LI, Y.; ZHU, J.; WU, H.; LIU, C.; HUANG, C.; LAN, J.; ZHAO, Y.; XIE, C. Precise base editing of nonallelic acetolactate synthase genes confers sulfonylurea herbicide resistance in maize. Crop Journal, v.8, n.3, p.449-456, 2020b. https://doi.org/10.1016/j.cj.2019.10.001

LI, Z.; LIU, Z. Bin; XING, A.; MOON, B. P.; KOELLHOFFER, J. P.; HUANG, L.; WARD, R. T.; CLIFTON, E.; FALCO, S. C.; CIGAN, A. M. Cas9guide RNA directed genome editing in soybean. Plant Physiology, v.169, n.2, p.960-970, 2015. https://doi.org/10.1104/pp.15.00783

LIANG, Z.; CHEN, K.; LI, T.; ZHANG, Y.; WANG, Y.; ZHAO, Q.; LIU, J.; ZHANG, H.; LIU, C.; RAN, Y.; GAO, C. Efficient DNA-free genome editing of bread wheat using CRISPR/Cas9 ribonucleoprotein complexes. Nature Communications, v.8, p.14261, 2017. https://doi.org/10.1038/ncomms14261

LIN, Q.; ZONG, Y.; XUE, C.; WANG, S.; JIN, S.; ZHU, Z.; WANG, Y.; ANZALONE, A. V; RAGURAM, A.; DOMAN, J. L.; LIU, D. R.; GAO, C. Prime genome editing in rice and wheat. Nature Biotechnology, v.38, n.5, p.582-585, 2020. https://doi.org/10.1038/s41587-020-0455-x

LIN, S.; STAAHL, B. T.; ALLA, R. K.; DOUDNA, J. A. Enhanced homology-directed human genome engineering by controlled timing of CRISPR/Cas9 delivery. elife, v.3, p.e04766, 2014. https://doi.org/10.7554/eLife.04766

LIU, C.; LI, X.; MENG, D.; ZHONG, Y.; CHEN, C.; DONG, X.; XU, X.; CHEN, B.; LI, W.; LI, L.; TIAN, X.; ZHAO, H.; SONG, W.; LUO, H.; ZHANG, Q.; LAI, J.; JIN, W.; YAN, J.; CHEN, S. A 4-bp insertion at zmpla1 encoding a putative phospholipase a generates haploid induction in maize. Molecular Plant, v.10, n.3, p.520-522, 2017. https://doi.org/10.1016/j.molp.2017.01.011

LOWE, K.; LA ROTA, M.; HOERSTER, G.; HASTINGS, C.; WANG, N.; CHAMBERLIN, M.; WU, E.; JONES, T.; GORDON-KAMM, W. Rapid genotype "independent" Zea mays L. (maize) transformation via direct somatic embryogenesis. In Vitro Cellular \& Developmental Biology Plant, v.54, n.3, p.240-252, 2018. https://doi.org/10.1007/s11627-018-9905-2

LOWE, K.; WU, E.; WANG, N.; HOERSTER, G.; HASTINGS, C.; CHO, M.-J.; SCELONGE, C.; LENDERTS, B.; CHAMBERLIN, M.; CUSHATT, J.; WANG, L.; RYAN, L.; KHAN, T.; CHOW-YIU, J.; 
HUA, W.; YU, M.; BANH, J.; BAO, Z.; BRINK, K.; IGO, E.; RUDRAPPA, B.; SHAMSEER, P. M.; BRUCE, W.; NEWMAN, L.; SHEN, B.; ZHENG, P.; BIDNEY, D.; FALCO, C.; REGISTER, J.; ZHAO, Z.-Y.; XU, D.; JONES, T.; GORDON-KAMM, W. Morphogenic Regulators BABY BOOM and WUSCHEL improve monocot transformation. The Plant Cell, v.28, n.9, p.1998-2015, 2016. https://doi.org/10.1105/tpc.16.00124

MA, C.; QU, H. Gametophytic self-incompatibility in rosaceae fruit trees. Acta Scientiarum Polonorum, Hortorum Cultus, v.18, n.4, p.149156, 2019. https://doi.org/10.24326/asphc.2019.4.14

MA, C.; ZHU, C.; ZHENG, M.; LIU, M.; ZHANG, D.; LIU, B.; LI, Q.; SI, J.; REN, X.; SONG, H. CRISPR/Cas9-mediated multiple gene editing in Brassica oleracea var. capitata using the endogenous tRNA-processing system. Horticulture Research, v.6, n.1, p.1-15, 2019. https://doi.org/10.1038/s41438-018-0107-1

MA, W.; XU, Y. S.; SUN, X. M.; HUANG, H. Transposon-associated CRISPR-Cas system: a powerful DNA insertion tool. Trends in Microbiology, v.29, n.7, p.565-569, 2021. https://doi.org/10.1016/j.tim.2021.01.017

MACNAGHTEN, P.; HABETS, M. G. J. L. Breaking the impasse: towards a forward-looking governance framework for gene editing with plants. Plants, People, Planet, v.2, n.4, p.353365, 2020. https://doi.org/10.1002/ppp3.10107

MAHAS, A.; NEAL STEWART, C.; MAHFOUZ, M. M. Harnessing CRISPR/Cas systems for programmable transcriptional and posttranscriptional regulation. Biotechnology Advances, v.36, n.1, p.295-310, 2017. https://doi.org/10.1016/j.biotechadv.2017.11.00 $\underline{8}$

MOOKKAN, M.; NELSON-VASILCHIK, K.; HAGUE, J.; ZHANG, Z. J.; KAUSCH, A. P. Selectable marker independent transformation of recalcitrant maize inbred B73 and sorghum P898012 mediated by morphogenic regulators BABY BOOM and WUSCHEL2. Plant cell reports, v.36, n.9, p.14771491, 2017. https://doi.org/10.1007/s00299017-2169-1

MUÑOZ-SANZ, J. V.; ZURIAGA, E.; CRUZ-GARCÍA,
F.; MCCLURE, B.; ROMERO, C. Self(In)compatibility systems: target traits for cropproduction, plant breeding, and biotechnology. Frontiers in Plant Science, v.11, n.195, p.1-24, 2020. https://doi.org/10.3389/fpls.2020.00195

NAGY, E. D.; STEVENS, J. L.; YU, N.; HUBMEIER, C. S.; LAFAVER, N.; GILLESPIE, M.; GARDUNIA, B.; CHENG, Q.; JOHNSON, S.; VAUGHN, A. L.; VEGASANCHEZ, M. E.; DENG, M.; RYMARQUIS, L.; LAWRENCE, R. J.; GARVEY, G. S.; GAETA, R. T. Novel disease resistance gene paralogs created by CRISPR/Cas9 in soy. Plant Cell Reports, v.40, p.1047-1058, 2021. https://doi.org/10.1007/s00299-021-02678-5

OSAKABE, Y.; WATANABE, T.; SUGANO, S. S.; UETA, R.; ISHIHARA, R.; SHINOZAKI, K.; OSAKABE, $K$. Optimization of CRISPR/Cas9 genome editing to modify abiotic stress responses in plants. Scientific Reports, v.6, n.26685, 2016. https://doi.org/10.1038/srep26685

OZUNA, C. V.; IEHISA, J. C. M.; GIMÉNEZ, M. J.; ALVAREZ, J. B.; SOUSA, C.; BARRO, F. Diversification of the celiac disease $\alpha$-gliadin complex in wheat: A 33-mer peptide with six overlapping epitopes, evolved following polyploidization. Plant Journal, v.82, n.5, p.794805, 2015. https://doi.org/10.1111/tpj.12851

PATHI, K. M.; RINK, P.; BUDHAGATAPALLI, N.; BETZ, R.; SAADO, I.; HIEKEL, S.; BECKER, M.; DJAMEI, A.; KUMLEHN, J. Engineering smut resistance in maize by site-directed mutagenesis of LIPOXYGENASE 3. Frontiers in Plant Science, v. 11, n.543895, p.1-13, 2020. https://doi.org/10.3389/fpls.2020.543895

PODEVIN, N.; DEVOS, Y.; DAVIES, H. V.; NIELSEN, K. M. Transgenic or not? No simple answer! EMBO reports, v.13, n.12, p.1057-1061, 2012. https://doi.org/10.1038/embor.2012.168

PUCHTA, $H$. The repair of double-strand breaks in plants: mechanisms and consequences for genome evolution. Journal of Experimental Botany, v.56, n.409, p.1-14, 2005. https://doi.org/10.1093/ixb/eri025

PUCHTA, H.; DUJON, B.; HOHN, B. Homologous recombination in plant cells is enhanced by in vivo induction of double strand breaks into DNA by a site-specific endonuclease. Nucleic Acids 
Research, v.21, n.22, p.5034-5040, 1993. https://doi.org/10.1093/nar/21.22.5034

PUCHTA, H.; DUJON, B.; HOHN, B. Two different but related mechanisms are used in plants for the repair of genomic double-strand breaks by homologous recombination. PNAS, v.93, n.10, p.5055-5060, 1996.

https://doi.org/10.1073/pnas.93.10.5055

QI, X.; WU, H.; JIANG, H.; ZHU, J.; HUANG, C.; ZHANG, X.; LIU, C.; CHENG, B. Conversion of a normal maize hybrid into a waxy version using in vivo CRISPR/Cas9 targeted mutation activity. Crop Journal, v.8, n.3, p.440-448, 2020a. https://doi.org/10.1016/i.cj.2020.01.006

QI, X.; ZHANG, C.; ZHU, J.; LIU, C.; HUANG, C.; LI, $X . ; \quad X I E, C$. Genome editing enables nextgeneration hybrid seed production technology. Molecular Plant, v.13, n.9, p.1262-1269, 2020 b. https://doi.org/10.1016/j.molp.2020.06.003

QIN, X.; LI, W.; LIU, Y.; TAN, M.; GANAL, M.; CHETELAT, R. T. A farnesyl pyrophosphate synthase gene expressed in pollen functions in SRNase-independent unilateral incompatibility. Plant Journal, v.93, n.3, p.417-430, 2018. https://doi.org/10.1111/tpj.13796

RAMAN, R. The impact of Genetically Modified (GM) crops in modern agriculture: a review. GM Crops \& Food, v.8, n.4, p.195-208, 2017. https://doi.org/10.1080/21645698.2017.1413522

RÖNSPIES, M.; SCHINDELE, P.; PUCHTA, H. CRISPR/Cas-mediated chromosome engineering: opening up a new avenue for plant breeding. Journal of Experimental Botany, v.72, n.2, p.177183, 2021. https://doi.org/10.1093/jxb/eraa463

SALOMON, S.; PUCHTA, H. Capture of genomic and T-DNA sequences during double-strand break repair in somatic plant cells. The EMBO Journal, v.17, n.20, p.6086-6095, 1998. https://doi.org/10.1093/emboi/17.20.6086

SÁNCHEZ-LEÓN, S.; GIL-HUMANES, J.; OZUNA, C. V.; GIMÉNEZ, M. J.; SOUSA, C.; VOYTAS, D. F.; BARRO, F. Low-gluten, nontransgenic wheat engineered with CRISPR/Cas9. Plant Biotechnology Journal, v.16, n. 4, p.902-910, 2018. https://doi.org/10.1111/pbi.12837
SCHEBEN, A.; EDWARDS, D. Bottlenecks for genome-edited crops on the road from lab to farm. Genome Biology, v.19, n.1, p.178, 2018. https://doi.org/10.1186/s13059-018-1555-5

SCHIML, S.; FAUSER, F.; PUCHTA, H. The CRISPR/Cas system can be used as nuclease for in planta gene targeting and as paired nickases for directed mutagenesis in Arabidopsis resulting in heritable progeny. Plant Journal, v.80, n.6, p.1139-1150, 2014.

https://doi.org/10.1111/tpj.12704

SCHINDELE, P.; WOLTER, F.; PUCHTA, H. Transforming plant biology and breeding with CRISPR/Cas9, Cas12 and Cas13. FEBS Letters, v.592, n.12, p.1954-1967, 2018. https://doi.org/10.1002/1873-3468.13073

SHAN, Q.; WANG, Y.; LI, J.; ZHANG, Y.; CHEN, K.; LIANG, Z.; ZHANG, K.; LIU, J.; XI, J. J.; QIU, J.-L.; GAO, C. Targeted genome modification of crop plants using a CRISPR-Cas system. Nature Biotechnology, v.31, n.8, p.686-688, 2013. https://doi.org/10.1038/nbt.2650

SHELAKE, R. M.; PRAMANIK, D.; KIM, J. Y. Exploration of plant-microbe interactions for sustainable agriculture in CRISPR era. Microorganisms, v.7, n.8, p.1-32, 2019. https://doi.org/10.3390/microorganisms7080269

SHI, J.; GAO, H.; WANG, H.; LAFITTE, H. R.; ARCHIBALD, R. L.; YANG, M.; HAKIMI, S. M.; MO, H.; HABBEN, J. E. ARGOS8 variants generated by CRISPR-Cas9 improve maize grain yield under field drought stress conditions. Plant Biotechnology Journal, v.15, n.2, p.207-216, 2017. https://doi.org/10.1111/pbi.12603

SHIMATANI, Z.; KASHOJIYA, S.; TAKAYAMA, M.; TERADA, R.; ARAZOE, T.; ISHII, H.; TERAMURA, H.; YAMAMOTO, T.; KOMATSU, H.; MIURA, K.; EZURA, H.; NISHIDA, K.; ARIIZUMI, T.; KONDO, A. Targeted base editing in rice and tomato using a CRISPR-Cas9 cytidine deaminase fusion. Nature Biotechnology, v.35, n.5, p.441-443, 2017. https://doi.org/10.1038/nbt.3833.

SHMAKOV, S.; ABUDAYYEH, O. O.; MAKAROVA, K. S.; WOLF, Y. I.; GOOTENBERG, J. S.; SEMENOVA, E.; MINAKHIN, L.; JOUNG, J.; KONERMANN, S.; SEVERINOV, K.; ZHANG, F.; KOONIN, E. V. Discovery and functional characterization of 
diverse class 2 CRISPR-Cas systems. Molecular Cell, v.60, n.3, p.385-397, nov. 2015. https://doi.org/10.1016/j.molcel.2015.10.008

SPRINGMANN, M.; CLARK, M.; MASON-D'CROZ, D.; WIEBE, K.; BODIRSKY, B. L.; LASSALETTA, L.; DE VRIES, W.; VERMEULEN, S. J.; HERRERO, M.; CARLSON, K. M.; JONELL, M.; TROELL, M.; DECLERCK, F.; GORDON, L. J.; ZURAYK, R.; SCARBOROUGH, P.; RAYNER, M.; LOKEN, B.; FANZO, J.; GODFRAY, H. C. J.; TILMAN, D.; ROCKSTRÖM, J.; WILLETT, W. Options for keeping the food system within environmental limits. Nature, v.562, n.7728, p.519-525, 2018. https://doi.org/10.1038/s41586-018-0594-0

SPRINK, T.; ERIKSSON, D.; SCHIEMANN, J.; HARTUNG, F. Regulatory hurdles for genome editing: process- vs. product-based approaches in different regulatory contexts. Plant cell reports, v.35, n.7, p.1493-1506, jul. 2016. https://doi.org/10.1007/s00299-016-1990-2

SUGANO, S.; HIROSE, A.; KANAZASHI, Y.; ADACHI, K.; HIBARA, M.; ITOH, T.; MIKAMI, M.; ENDO, M.; HIROSE, S.; MARUYAMA, N.; ABE, J.; YAMADA, T. Simultaneous induction of mutant alleles of two allergenic genes in soybean by using site-directed mutagenesis. BMC Plant Biology, v.20, n.513, p.1-15, 2020. https://doi.org/10.1186/s12870020-02708-6

SUN, Y.; ZHANG, X.; WU, C.; HE, Y.; MA, Y.; HOU, H.; GUO, X.; DU, W.; ZHAO, Y.; XIA, L. Engineering herbicide-resistant rice plants through CRISPR/Cas9-mediated homologous recombination of acetolactate synthase. Molecular Plant, v.9, n.4, p.628-631, 2016. https://doi.org/10.1016/j.molp.2016.01.001

SVITASHEV, S.; SCHWARTZ, C.; LENDERTS, B.; YOUNG, J. K.; MARK CIGAN, A. Genome editing in maize directed by CRISPR-Cas9 ribonucleoprotein complexes. Nature Communications, v.7, n.13274, 2016.

https://doi.org/10.1038/ncomms13274

TURNBULL, C.; LILLEMO, M.; HVOSLEF-EIDE, T. A. K. Global Regulation of Genetically Modified Crops Amid the Gene Edited Crop Boom - A Review. Frontiers in Plant Science, v.12, p.258, 2021. https://doi.org/10.3389/fpls.2021.630396

URNOV, F. D.; RONALD, P. C.; CARROLL, D. A call for science-based review of the European court's decision on gene-edited crops. Nature Biotechnology, v.36, n.9, p.800-802, 2018. https://doi.org/10.1038/nbt.4252

VAN EENENNAAM, A. L.; WELLS, K. D.; MURRAY, J. D. Proposed U.S. regulation of gene-edited food animals is not fit for purpose. npj Science of Food, v.3, n.3, 2019. https://doi.org/10.1038/s41538-019-0035-y

VEILLET, F.; PERROT, L.; CHAUVIN, L.; KERMARREC, M. P.; GUYON-DEBAST, A.; CHAUVIN, J. E.; NOGUÉ, F.; MAZIER, M. Transgene-free genome editing in tomato and potato plants using Agrobacterium-mediated delivery of a CRISPR/Cas9 cytidine base editor. International Journal of Molecular Sciences, v.20, n.2, 2019. https://doi.org/10.3390/ijms20020402

VOLPI E SILVA, N.; ANGELOTTI-MENDONÇA, J.; BARBOSA, E. G. G.; GIROTTO, L.; MOLINARI, M. D. C.; MERTZ-HENNING, L. M.; NEPOMUCENO, A. L. Edição de genoma por CRISPR/Cas via recombinação homóloga. In: MOLINARI, H. B. C.; VIEIRA, L. R.; VOLPI E SILVA, N.; PRADO, G. S.; FILHO, J. H. L. (Ed.). Tecnologia CRISPR na edição genômica de plantas Biotecnologia aplicada à agricultura. Brasília: Embrapa, 2020. p.93-126.

VOYTAS, D. F.; GAO, C. Precision Genome Engineering and Agriculture: Opportunities and Regulatory Challenges. PLoS Biology, v.12, n.6, p.e1001877,

2014.

https://doi.org/10.1371/journal.pbio.1001877

WALTZ, E. With a free pass, CRISPR-edited plants reach market in record time. Nature Biotechnology, v.36, p.6-7, 2018. https://doi.org/10.1038/nbt0118-6b

WANG, B.; ZHU, L.; ZHAO, B.; ZHAO, Y.; XIE, Y.; ZHENG, Z.; LI, Y.; SUN, J.; WANG, H. Development of a haploid-inducer mediated genome editing system for accelerating maize breeding. Molecular Plant, v. 12, n. 4, p. 597-602, 2019a. https://doi.org/10.1016/j.molp.2019.03.006

WANG, C.; LIU, Q.; SHEN, Y.; HUA, Y.; WANG, J.; LIN, J.; WU, M.; SUN, T.; CHENG, Z.; MERCIER, R.; WANG, K. Clonal seeds from hybrid rice by simultaneous genome engineering of meiosis and fertilization genes. Nature Biotechnology, v.37, 
n.3,

p.283-286,

2019b.

https://doi.org/10.1038/s41587-018-0003-0

WANG, F.; WANG, C.; LIU, P.; LEI, C.; HAO, W.; GAO, Y.; LIU, Y. G.; ZHAO, K. Enhanced rice blast resistance by CRISPR/ Cas9-Targeted mutagenesis of the ERF transcription factor gene OsERF922. PLoS ONE, v.11, n.4, p.e0154027, 2016. https://doi.org/10.1371/journal.pone.0154027

WANG, Y.; CHENG, X.; SHAN, Q.; ZHANG, Y.; LIU, J.; GAO, C.; QIU, J. L. Simultaneous editing of three homoeoalleles in hexaploid bread wheat confers heritable resistance to powdery mildew. Nature Biotechnology, v.32, p.947-951, 2014. https://doi.org/10.1038/nbt.2969

WOO, J. W.; KIM, J. J.-S.; KWON, S. II; CORVALÁN, C.; CHO, S. W.; KIM, H.; KIM, S.-T. S.-G.; KIM, S.-T. S.-G.; CHOE, S.; KIM, J. J.-S. DNA-free genome editing in plants with preassembled CRISPR-Cas9 ribonucleoproteins. Nature Biotechnology, v.33, p.1162-1164, 2015.

https://doi.org/10.1038/nbt.3389

WU, J.; CHEN, C.; XIAN, G.; LIU, D.; LIN, L.; YIN, S.; SUN, Q.; FANG, Y.; ZHANG, H.; WANG, Y. Engineering herbicide-resistant oilseed rape by CRISPR/Cas9-mediated cytosine base-editing. Plant Biotechnology Journal, v.18, p. 1857-1859, 2020. https://doi.org/10.1111/pbi.13368

XU, J.; YIN, Y.; JIAN, L.; HAN, B.; CHEN, Z.; YAN, J.; LIU, $X$. Seeing is believing: a visualization toolbox to enhance selection efficiency in maize genome editing. Plant Biotechnology Journal, v.19, p.872-874, 2021a. https://doi.org/10.1111/pbi.13575

XU, R.-F.; LI, H.; QIN, R.-Y.; LI, J.; QIU, C.-H.; YANG, Y.-C.; MA, H.; LI, L.; WEI, P.-C.; YANG, J.-B. Generation of inheritable and "transgene clean" targeted genome-modified rice in later generations using the CRISPR/Cas9 system. Scientific reports, v.5, p.11491, 2015. https://doi.org/10.1038/srep11491

XU, Y.; LIN, Q.; LI, X.; WANG, F.; CHEN, Z.; WANG, J.; LI, W.; FAN, F.; TAO, Y.; JIANG, Y.; WEI, X.; ZHANG, R.; ZHU, Q. H.; BU, Q.; YANG, J.; GAO, C. Fine-tuning the amylose content of rice by precise base editing of the $W x$ gene. Plant Biotechnology Journal, v.19, n.1, p.11-13, 2021b. https://doi.org/10.1111/pbi.13433
YAO, L.; ZHANG, Y.; LIU, C.; LIU, Y.; WANG, Y.; LIANG, D.; LIU, J.; SAHOO, G.; KELLIHER, T. OsMATL mutation induces haploid seed formation in indica rice. Nature Plants, v.4, p.530-533, 2018.

https://doi.org/10.1038/s41477-018-0193-y

YU, Q. H.; WANG, B.; LI, N.; TANG, Y.; YANG, S.; YANG, T.; XU, J.; GUO, C.; YAN, P.; WANG, Q.; ASMUTOLA, P. CRISPR/Cas9-induced targeted mutagenesis and gene replacement to generate long-shelf life tomato lines. Scientific Reports, v.7, n.1, p.1-9, 2017. https://doi.org/10.1038/s41598-017-12262-1

YUAN, M.; ZHU, J.; GONG, L.; HE, L.; LEE, C.; HAN, S.; CHEN, C.; HE, G. Mutagenesis of FAD2 genes in peanut with CRISPR/Cas9 based gene editing. BMC Biotechnology, v.19, p.24, 2019. https://doi.org/10.1186/s12896-019-0516-8

ZHANG, R.; CHEN, S.; MENG, X.; CHAI, Z.; WANG, D.; YUAN, Y.; CHEN, K.; JIANG, L.; LI, J.; GAO, C. Generating broad-spectrum tolerance to ALSinhibiting herbicides in rice by base editing. Science China Life Sciences, 2020a. https://doi.org/10.1007/s11427-020-1800-5

ZHANG, Y.; BAI, Y.; WU, G.; ZOU, S.; CHEN, Y.; GAO, C.; TANG, D. Simultaneous modification of three homoeologs of TaEDR1 by genome editing enhances powdery mildew resistance in wheat. Plant Journal, v.91, p.714-724, 2017. https://doi.org/10.1111/tpj.13599

ZHANG, Y.; PRIBIL, M.; PALMGREN, M.; GAO, C. A CRISPR way for accelerating improvement of food crops. Nature Food, v.1, p.200-205, 2020b. https://doi.org/10.1038/s43016-020-0051-8

ZHOU, X.; JACOBS, T. B.; XUE, L. J.; HARDING, S. A.; TSAI, C. J. Exploiting SNPs for biallelic CRISPR mutations in the outcrossing woody perennial Populus reveals 4-coumarate: CoA ligase specificity and redundancy. New Phytologist, v.208, p.298-301, 2015. https://doi.org/10.1111/nph.13470

ZHU, H.; LI, C.; GAO, C. Applications of CRISPRCas in agriculture and plant biotechnology. Nature Reviews Molecular Cell Biology, v.21, n.11, p.661-677, 2020. https://doi.org/10.1038/s41580-020-00288-9 
ZONG, Y.; WANG, Y.; LI, C.; ZHANG, R.; CHEN, K.; RAN, Y.; QIU, J.-L.; WANG, D.; GAO, C. Precise base editing in rice, wheat and maize with a Cas9-

cytidine deaminase fusion.

Nature

Biotechnology, v.35, n.5, p.438-440, 2017.

https://doi.org/10.1038/nbt.3811 